\title{
Avaliação Microbiológica de Sorvetes Comercializados no Município de Frederico Westphalen
}

Gilson Parussolo (I), Janaína Schmitt (I,II,I), Patche Helena Michel $(I, I)$, Rita Tatiana Busatto $(I, I)$, Edi Franciele Ries (I), Vanessa Pires da Rosa (I)

(I) UFSM - Universidade Federal de Santa Maria (Linha Sete de Setembro), (II) UFSM Universidade Federal de Santa Maria (Linha Sete de Setembro)

\section{Resumo}

O sorvete é o derivado lácteo mais apreciado principalmente na época do verão por todas as faixas etárias, exigindo preocupação com boas práticas de fabricação e segurança alimentar. O mesmo por conter nutrientes, apresenta-se como excelente meio de cultura para proliferação bacteriana resistente ao congelamento. $\mathrm{O}$ objetivo deste trabalho foi avaliar microbiologicamente sorvetes comercializados no município de Frederico Westphalen. Foram escolhidos dois estabelecimentos X e Y aleatoriamente onde foram coletadas amostras de sorvete de chocolate (A), morango (B), nozes (C), creme (D) e flocos (E), nas condições de consumo pelo consumidor. Após, as amostras foram enviadas para análise no Laboratório de Análises Microbiológicas da UFSM-CAFW onde realizou-se a contagem de Psicotróficos, Staphylococcus coagulase positiva, Coliformes totais e termotolerantes e Salmonella sp.. Analisando os dados obtidos, de acordo com a RDC 12, as amostras de sorvetes coletadas do estabelecimento $X$ estão próprias para consumo, apresentando ausência de Coliformes, Staphylococcus coagulase positiva e Salmonella sp.. Embora a legislação não estabeleça limites para contagem de Psicotróficos, observouse presença em todas as amostras analisadas, provavelmente sua origem foi de uma má higienização dos utensílios utilizados para fabricação do sorvete. Para o estabelecimento Y, observou-se ausência de Staphylococcus

\footnotetext{
Referência:

Gilson Parussolo, Janaína Schmitt, Patche Helena Michel, Rita Tatiana Busatto, Edi Franciele Ries, Vanessa Pires da Rosa.Avaliação Microbiológica de Sorvetes Comercializados no Município de Frederico Westphalen. In: Anais do 12을 Congresso Latinoamericano de Microbiologia e Higiene de Alimentos - MICROAL 2014 [= Blucher Food Science Proceedings, num.1, vol.1]. São Paulo: Editora Blucher, 2014.

DOI 10.5151/foodsci-microal-015
} 
coagulase positiva, Salmonella sp. e Psicotróficos. Apenas para coliformes totais todas as amostras apresentaram resultado positivo, sendo identificado ainda Coliforme termotolerante apenas na amostra B, evidenciando assim más condições no processamento, ou seja, essa contaminação possivelmente teve origem dos manipuladores, deixando assim, o sorvete impróprio para o consumo humano segundo a legislação vigente. Com isso, conclui-se que o sorvete do estabelecimento A pode ser comercializado, pois não apresentou contaminação, já para o sorvete do estabelecimento B observou-se falhas no preparo e manipulação do mesmo. Uma alternativa para corrigir essa não conformidade, seria auxiliar os funcionários sobre as Boas Práticas de Fabricação, fazendo com que este produto esteja conforme a legislação.

Palavras-Chave: segurança alimentar, , coliformes termotolerantes, derivado lácteo

\section{Agência de Fomento:}

